\title{
Incidence of Bipolaris and Exserohilum Species in Corn Leaves in North Carolina
}

\author{
K. J. LEONARD. Research Plant Pathologist, USDA-ARS, Department of Plant Pathology, Box 7616, North \\ Carolina State University, Raleigh 27695-7617; R. P. THAKUR, Plant Pathologist, Pearl Millet Improvement \\ Program, ICRISAT, Patancheru P.O.. Andhra Pradesh 502324, India; and S. LEATH, Research Plant Pathologist. \\ USDA-ARS. Department of Plant Pathology, Box 7616, North Carolina State University, Raleigh 27695-7616
}

\begin{abstract}
Leonard, K J., Thakur, R P , and Leath. S 1988 Incidence of Bipolaris and Evserohilum species in corn leaves in North Carolina Plant Disease 72 10.34-1038

Samples of 42-60 corn leaves were collected without regard to disease sy mptoms at 2-m intervals in each of eight cornfield in western and two in eastern North Carolina in 1985 Sampling dates for the 10 fields ranged from 16 July to 8 August The leaves were surface-sterilised and incubated in moist chambers for isolation of large-spored species of Bipolaris and Erserohilum Incidence of $B$ zeic ola infection was high $\left(41-811^{\circ}\right)$ in leaves from nine of the lofields $B$ maldis and $E$ : $u$ ro 1 um. which are more aggressive pathogens of hybrid corn than $B$ zeicola, occurred at lower incidences of $0-48 \%$ and $0-50^{\circ} \%$, respectively, in leaves from these fields at the time of sampling. This indicated that initral population densities of these aggressive pathogens were much lower than that of $\boldsymbol{B}$. zencola forty-five isolates of $F$ turcicum collected before 28 August were all race 1 Three isolates of race 2 were obtained later from fields of hybrids with the $H / l$ gene for resistance to race 1 All 75 isolates of $B$ maidis obtained from the 10 extensively sampled tields were race $O$, they were equally virulent on inbred lıne B73 with normal cytoplasm or B73 with C', S, or I male sterile cytoplasm Frequencies of mating types of $B$ maids and $B$ zeicola varied from field to field, with no correlation between the frequencies in the two species Races 2 and 3 of $B$ zelc ola. however, had similar mating type frequencies in these ficlds $B$ sorokiniana was isolated from leaves from six of the 10 fields, the greatest incidence was $.37^{\circ} \mathrm{C}$ E rostratum was found in leaves from five fields at incidences up to $18^{\circ}$, and $E$ holmu occurred in leaves in one field at II\% incidence These data Indicate that a variety of species of Bipolaris and Exserohilum are able to infect green leaves of mature corn plants in the field I hus, corn may contribute to the survival of species that ate primarily pathogenic on other gramıneous hosts
\end{abstract}

Additional keywords Cochlobolus arbonum, ( heterostrophus, maise, northern leat blight. southern leaf blight. Zea mas

As a continuation of studies of genetic variation in populations of Bipolarts zeicola (Stout) Shoemaker (telıomorph Cochlioholus carbonum Nelson) (14,19), we sampled leaves of corn (Zea mais L.) in 10 fields in North Carolina in 1985 In isolatıng $B$. zeicola from these leaves, we realized that several species of Bipolaris and Exserohilum were present at relatively high incidences in leaves from many of the fields. Not all of the species we found are generally regarded as pathogens of corn, and those species that are known as important corn pathogens were not always found with the greatest

Present address of first author USDA Cereal Rust Laboratory, University of Minnesota, St Paul, MN 55108

Journal Article 761 of the International Crops Research Institute for the Semi-Arid 1 ropics (ICRISA I) Paper No 11409 of the Journal Series of the North Carolina Agricultural Research Service, Raleigh 27695-7601

Cooperative investigations of the USDA-ARS and North Carolina Agricultural Research Service

Accepted for publication 12 July 1988 (submitted fot electronic processing)

This articie is in the public domain and not copyrightable it may be freely reprinted with customary crediting of the source The American Phytopathological Society, 1988 frequency. Consequently, we expanded the study to include all of the largespored species of Bipolaris and Exserohilum that occurred in the leaves collected. A more detailed analysis of genetic variation within the $B$. zeicola populations in these fields will be reported in a separate paper.

In this paper, we report on virulence and mating types of two important leat blight pathogens of corn: Bipolaris maydls (Nisikado) Shoemaker (telıomorph $C$. heterostrophus Drechs.), the cause of southern corn leaf blight, and Exserohilum turcicum (Pass.) l.eonard \& Suggs (telinmorph Setosphaeria turcica (Luttrell) Leonard \& Suggs.), the cause of northern leaf blight. Two races, race $\mathrm{O}$ and race $T$, of $B$. maydis have been described in the United States, although race $T$, which is specifically virulent on corn with Texas male sterile cytoplasm (cms-T), has not been important in recent years $(13,15)$. In China, Wei et al $(28)$ recently discovered a third race, race $C$, which produces a host-specific toxin specifically actıve against corn lines with $\mathrm{C}$ male sterile cytoplasm (cms-C). Cms-C has been used, although sparingly, as an alternative to cms-T in the production of hybrid corn seed in the United States, so we felt that it would be important to screen our isolates for virulence not only on corn with cms-T but also on corn with cms-C.

The HIl gene for chlorotic lesion resistance to northern leaf blight has been widely, although not exclusively, used in corn hybrids grown in the United States. Because northern leaf blight is generally less important in the southeastern United States than in the Corn Belt. $\mathrm{Hrl}$ has been less widely used in the Southeast. Berquist and Masias (2) first reported the occurrence of race 2 of $E$. iurcicum. which was not controlled by $\mathrm{HIl}$ resistance, in corn in Hawail. Race 2 was tound in Indiana in 1979 (26). By 1981, race 2 had been found throughout the Corn Belt as well as in New York, Pennsylvana, and Florida $(5,18)$. The development of a northern leaf blight epidemic in August 1985 in corn in several counties of western North Carolina, where $H I l$ had not been used widely, provided an opportunity to examine relative frequencies of races 1 and 2 in the absence of strong host selection for race 2 .

Kline and Nelson $(6,22)$ reported that many species of Bipolaris have rather broad host ranges and that species commonly associated with grasses or small grains can infect corn seedlings in the greenhouse. Their tests were done with high inoculum doses and under conditions extremely favorable for infection. The occurrence of several Bipolaris and Exserohilum species in leaf samples from the fields in 1985 provided a test of the ability of some of these grass and small grain pathogens to infect and survive in corn under field conditions. The results reported herein provide insight into the role of alternative hosts in the survival of leaf-infecting species of Bipolaris and Exserohilum.

The corn leaves in the sampled fields were collected without regard to disease symptoms. Thus, our objectives in this survey were to obtain an unbiased estimate of the relative prevalence of Bipolaris and Exserohilum species in leaves of corn plants in the field and, in the case of important corn pathogens, to obtain estimates of the prevalence of pathogenic races and of mating types among the isolates obtained.

\section{MATERIALS AND METHODS}

Ten cornfields in North Carolina were sampled extensively for leaf-inhabiting species of Bipolaris and Exserohilum in 
1985 One leaf uds taken per plant dt dpproximatels $2-m$ interials in d portion of each field The sampled ledies were a mong the oldest leaves that had not yet senesced on the plants. and thes were collected without regard to simptoms Leaves from 60) plants were collected in fields $1-9$ and from 42 plants in field 10

Six of the sampled fields were in Wilkes Count which lies just edst of the Blue Ridge Mountains in western North Carolina (Fig 1) Elevations of these $41 x$ field, ranged from 283 to $450 \mathrm{~m}$ I wo othei sampled fields also were in western North Carolina field 6 (elesation $326 \mathrm{~m}$ ) in Yadkin Counts just east of Wilkes County, and tield 9 (eletation $370 \mathrm{~m}$ ) in McDowell County, southwest of Wilkes County and just east of the Blue Ridge Mountains The other two sampled ficlds were in Wakt (ounty (eleiation $102 \mathrm{~m}$ ) and Edgecombe (ounty (elevation $38 \mathrm{~m}$ ) in edstern Vorth (arolind Edch field uas sampled once with sampling dates ranging from 16 Julv to 8 August 1985

In early August 1985 northern leaf blight lesions were reported in mans fields in western Morth (arolind so we collected symptomatic leascs from 14 additional ficlds all but one of which were in five western North Carolind counties (f ig 2) Isolates of $L$ turcicum were obtained from one or two northern leaf blight lesions from each of these 14 fields

Ihe leaves from the extensively sampled fields were dried in a plant press and kept dt room temperature untul they could be incubated for isoldtion of Bipolaris and Liserohilum species Because conidia deposited on the surface of corn leaves either in the field or in the laboratory as contaminants can germinate and produce sporulating colonies on the leaf surface within 2 or 3 days (9), it was necessary to surface-sterilye the collected leaves immediately before incubation Preces up $108 \mathrm{~cm}$ long and several centımeters wide were cut from each leat and surface-sterilized by immersion for $30 \mathrm{sec}$ in $70 \%$ ethanol followed by $30 \mathrm{sec}$ in $05 \%$ sodium hypochlorite solution The leaf pieces were rinsed in tap water and incubated on wet filter paper in petrı dishes at room temperature under fluorescent light with a 12-hr photoperiod

After 2-4 days, the incubated leaf pieces were examined under a stereo microscope at $25 \times$ for conidiophores and conidia of large-spored species of Bıpolarts and Exserohilum A representatıve of each type present on each leaf was collected by picking conidia directly from the conidiophores with a sterile needle The conidia were transferred to potato-dextrose agar (PDA) with $10 \mathrm{gm}$ of dextrose per liter The resulting cultures were transferred once to ensure purity, after which the isolates were stored as conidial suspensions in $30 \%$ glycerol frozen at $-70 \mathrm{C}$

Inocula for tests of virulence of
Bipolari and frerohilum isolater nete prepared bi washing conidia from 7- to 10-dai-old cultures on PDA for Bipolars species of on lactose-casein hrdrolssate agar (25) for $I$ turculum (ondial suspensions were filtered through tous suspensions were sprased onto corn seedlings in the four- to six-leat stage with a Delilbis dtomizer attached to an dir pump and the inoculated plants wete incubated overnight in a mosst chamber Atomizers were rinsed with 70 , ethanol betueen inoculations for soldtes of Bipolarm species, seedlings of Proneet Brand $3369 \mathrm{~A}$ were inoculated in the initial virulence tests lsolates of $B$ maids also were inoculated onto seedlings of B73 with normal citoplasm c ms-C (m)- ol c $\mathrm{m})-1$ lsoldtes of $f$ turc ic um were inoculated onto secedlings of Pioneer Brand 3065 which lachs the Hil gene for resstance to northern leat blight and Pioneer Brand 3535 which has the Hil gene Inedse teactions were elaluated atter I $\mathrm{wk}$ for Bipolaris species and atter 2 wh for $I$ turcicum

Mating tvpes of solates of $B$ zercola and $B$ maids were determined bi paring each isoldte with hnoun tester soldtes of MAII-1 and MAII-2 (f ormerly designated matung tvpes $A$ and d. respectively) of each species Mycelial plugs for paired isolates from 5- to 7-davold cultures on PDA wete placed on opposite sides of autoclaved $1-\mathrm{cm}$ diameter disks of senescent corn leaves laters of cheesecloth Ihe condial

on moditied Sach agar (4) in petrı dishes Pseudothecla formed within 7 dass in fertile combinations and the pseudothecia were crushed and examined for ascl and abcospores alter $21 \mathrm{dal}$

Matung tspes of soldtes of $I$ turcic um and $l$ hoimu (l uttrell) I eonard \& Suggs (teliomoiph Setosphaera holmu (I uttrell) Leonard \& Suggs) ucte determined br parting micelial plugs from PI)A cultures of unhnoun solates and knoun matung tipe testers approximatels $1 \mathrm{~cm}$ apart on sterilised barles grains on moditied sachs agas in petri dishes Pseudothecid of 5 turcka it thes formed nere ciushed and examined for asc and ascospores after 20)-25 dats Pecudothecid of 5 holmut were examined after 18 dals

\section{RFSUI TS}

Incidence. $B$ ze'cola oucurred at high trequencies in leases of coin plants in nine of the 10 extensively sampled fields (Iable I) even though the leaves wete collected independently of the presence of leat spot svmptoms $B$ malds and $l$ turcicum were more erratk in thell distribution and occuited at lower frequencies than $B$ ze'tcola at the time of sampling from mid-July to early August Surprisingly $B$ sorokimiana (Sace in Sorok / Shoemahet, d pathogen of balley and wheat. Was piesent in corn ledves from six of the 10 tields In two of the fields, the incidence of $B$ sorohimiana was gredter than that of ether $B$ mavds

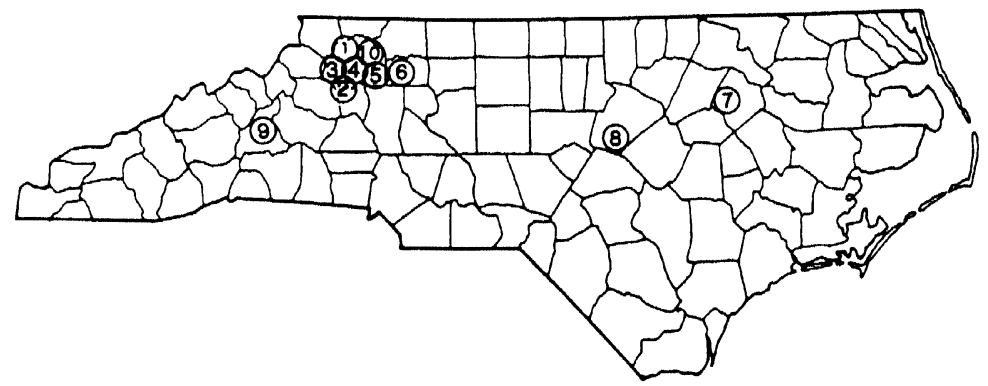

Fig 1 Locations of 10 cor nfielda in North (arolina that were extensively sampled for incidence of infections of large-spored species of Bipolaris and Lxserohilum in 1985

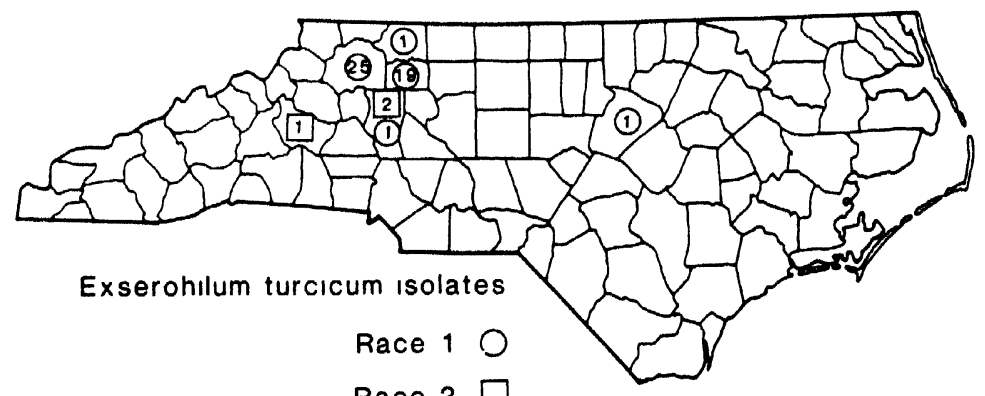

Race 2

Fig. 2. Distribution of race 1 and race 2 of Exserohilum turcicum isolates collected from cornfields in North Carolina in 1985 Numbers within the circles and squares indicate the number of isolates of race 1 and race 2 , respectively, obtained in the indicated county 


\section{or E turcicum}

An unidentified species of Bipolarts one in western and one in eastern North Carolina The unidentified species was morphologically similar to $B$ zetcola but was completely infertile in attempted matıngs with mating type testers of $B$ zescola furthermore, isolates of the unidentified species induced either no visible symptoms or only a few small flecks on inoculated leaves of corn seedlings The unidentified species also was distinguished from $B$ zell ola in that more than $75 \%$ of the solates of this species falled to grow or grew very poorly in PDA amended with $100 \mu \mathrm{g} / \mathrm{ml}$ of carboxin. whereas less than $10 \%$ of $B$ ze'cola ssolates were severely inhibited by sorokiniana, which is morphologically also falled to grow on PI)A with carboxın at $100 \mu \mathrm{g} / \mathrm{ml}$

t rostratum (Drechs) 1 eonard \& Suggs, a species known to have a broad host range, was found in corn leaves from five of the 10 fields Incidence of $L$ rostratum was low except in field $x$ in Wake County in eastern Nortlı Carolına One of the isolates from field 8 produced extremely long conidia, averaging $274 \times$ $156 \mu \mathrm{m}$, on the incubated leaf This isolate fits within the range described for $E$ longirostratum (Subram.) Sivanesan (24). but Leonard ana Suggs (17) regarded $E$ longirostratum as probably a variant of $E$ rostratum Isolates of $E$ rostratum induced small, round necrotic lesions on leaves of corn seedlings similar to, though generally smaller than, those induced by race 2 of $B$. zetcola

E. holmu, a leaf blight pathogen of the wild grass Dactvloctenium aegvptium (L) Richter (20), occurred in corn leaves only from the field in McDowell County in western North Carolina Isolates of $E$ holmu induced either no visible symptoms or only small flecks on inoculated leaves was found in corn leaves from two fields. carboxin at $100 \mu \mathrm{g} / \mathrm{ml}$ All solates of $B$ distinct from the unidentified species. of corn seedlings

Virulence. The frequencies of race 2 and race 3 of $B$ zeicola in the extensively sampled fields have been described briefly (8) and will be reported elsewhere in greater detail All of the $75 B$ mavds isolates from these fields were race 0 None showed any greater virulence to any of the cms lines of $B 73$ than to B73 with normal cytoplasm

None of the leaves collected from 16 to 28 July had northern leaf blight lesions (Table 1) In fact, only one northern leaf blight lesion (found in field 6 in Yadkın County) was observed in any of the helds sampled during that time Thus, the isolates of $E$ turcicum from leaves collected on 16 July from fields in Wilkes and Yadkın counties represented latent infections in the early stages of an epidemic that became apparent a few weeks later (16)

On 8 August, in response to calls from extension agents in these counties, we returned to Wilkes and Yadkın counties to obtain additional leaf samples In field 10, we collected 42 leaves without regard to symptoms and found $50 \%$ incidence of L turcicum In addition, we obtained seven more isolates from another field in Wilkes County and five fields in Yadkın County Other leaf samples with northern leaf blight lesions were sent by county agents to the North Carolina State University Plant Disease and Insect Clinic

Of the 50 solates of $E$ turc 1 cum that we obtained. 47 were race $I$ and only three were race 2 The three solates of race 2 were collected on hybrids with the Hil gene for resistance on 28 and 29 August (Table 2) All isolates of $E$ turc icum except the last isolate collected in September were from western North Carolina (Fig 2)

Mating type. Matıng type frequencies for isolates of $B$ maydis and $B$ zelcola from fields with more than $10 \%$ incidence of $B$ mayd $s$ are shown in Table 3 Both matung types of $B$ movdis were found in all of the fields from which more than five isolates of $B$ maidis were obtained Frequencies of MATI-1 in $B$ mavdis varied among the five fields with greater than $10 \%$ incidence of $B$ mal dis In these fields, the frequency of MATI-I was not correlated with the frequency of MATI-1 in $B$ zelcola $(r=-0$ 142) In three of the five fields, both race 2 and race 3 of $B$ zetcola occurred at greater than $10 \%$ incidence In those three fields, the frequencies of MATI-1 in race 2 were significantly correlated with the frequencies of MATI-1 in race $3(r=0954)$ Matıng types could be determined for only 12 of the $50 \mathrm{E}$ turcicum isolates Three race $I$ isolates were matung type $A$ and seven were matıng type a Two of the three race 2 isolates were fertile and were matıng type a All six of the $E$ holmu solates collected from field 9 were fertile. three were matung type $A$ and three were matıng type a lsolates of $E$ rostratum were not tested for matıng type because previous experience had shown that fertility is rare in this species (12)

\section{DISC USSION}

The high incidence of $B$ zelcola in cornfields may seem inconsistent with its relative lack of importance as a pathogen of corn Although $B$ zeicola is generally associated with corn production, it causes little or no yield loss (3) Race I of $B$ zelcola, which can cause severe losses on inbred lines ol hybrids of corn sensitive to its toxin (27), has rarely been found since the toxin-sensitive genotypes were removed from corn breeding programs (14) Fisher et al (3) found no yield loss in 19 hybrids inoculated with race 2 of $B$ zelcola, but $B$ mavdis race $O$ and $E$ turcicum caused yicld losses of 040 and $023 \%$, respectively, for each $1 \%$ disease severity at 3-4 wk after mid-silk stage (3)

The high incidence of $B$ zeicola in mid-

Table 2. Pathogenic races of Exserohilum turcicum isolated from leaves of Zea mays in North Carolina in 1985

Table 1. Incidence of Bipolaris and Exserohilum species" in leaves of Zea mays collected from 10 cornfields in North Caroline in 1985

\begin{tabular}{|c|c|c|c|c|c|c|c|c|c|}
\hline \multirow[b]{2}{*}{ County } & \multirow{2}{*}{$\begin{array}{c}\text { Field }^{b} \\
\text { no. }\end{array}$} & \multirow[b]{2}{*}{ Date } & \multicolumn{7}{|c|}{ Incidence $(\%)^{c}$} \\
\hline & & & $\mathbf{B z}$ & $\mathbf{B m}$ & Bs & B- & $\mathbf{E t}$ & $\mathbf{E r}$ & Eh \\
\hline Wilkes & 1 & $7 / 16$ & 63 & 22 & 3 & 0 & 0 & 0 & 0 \\
\hline Wilkes & 2 & $7 / 16$ & 70 & 13 & 0 & 0 & 0 & 5 & 0 \\
\hline Wilkes & 3 & $7 / 16$ & 67 & 2 & 4 & 0 & 4 & 2 & 0 \\
\hline Wilkes & 4 & 716 & 81 & 3 & 0 & 0 & 0 & 0 & 0 \\
\hline Wilkes & 5 & 716 & 41 & 0 & 20 & 0 & 2 & 0 & 0 \\
\hline Yadkın & 6 & 716 & 77 & 5 & 37 & 0 & 18 & 3 & 0 \\
\hline Edgecombe & 7 & $7 / 24$ & 66 & 22 & 0 & 0 & 0 & 0 & 0 \\
\hline McDowell & 9 & 725 & 11 & 12 & 9 & 25 & 0 & 11 & 11 \\
\hline Wake & 8 & $7 / 28$ & 62 & 48 & 2 & 3 & 0 & 32 & 0 \\
\hline Wilkes & 10 & $8 / 8$ & 95 & 5 & 0 & 0 & 50 & 0 & 0 \\
\hline
\end{tabular}

${ }^{\mathrm{B}} \mathrm{Bz}=$ Bipolarıs zeıcola, $\mathrm{Bm}=\mathrm{B}$ maldis, $\mathrm{Bs}-\mathrm{B}$ sorohınıana $\mathrm{B}$ - = unidentified Bıpolarıs $\mathrm{sp}$.

$\mathrm{Et}=$ Exserohilum turcicum, $\mathrm{Er}=E$ rostratum $\mathrm{Fh}=E$ holmu

${ }^{\text {b }}$ See Figure 1 for locutions

'Percentage of leaves from which the indicated species was solated Sample sizes were 60 leaves each in field $1-9$ and 42 leaves in field 10 Leaves were collected at $2-m$ intervals in fields without regard to symptoms

\begin{tabular}{|c|c|c|c|}
\hline \multirow[b]{2}{*}{ County } & \multirow[b]{2}{*}{ Date } & \multicolumn{2}{|c|}{ Number of isolates } \\
\hline & & Race I & Race 2 \\
\hline Wilkes" & $7 / 16$ & 3 & 0 \\
\hline Yadkın & $7 / 16$ & 11 & 0 \\
\hline Wilkes" & $8 / 8$ & 22 & 0 \\
\hline Yadkın ${ }^{d}$ & $8 / 8$ & 6 & 0 \\
\hline Surry & 812 & 1 & 0 \\
\hline Yadkın & 819 & 2 & 0 \\
\hline Iredell & 828 & 1 & 2 \\
\hline Burke & 829 & 0 & 1 \\
\hline Wake & 94 & 1 & 0 \\
\hline Total & & 47 & 3 \\
\hline
\end{tabular}

"Two isolates from field 3 , one from field 5 (see lable 1)

One isolate from unnumbered field, 21 from field 10

"lsolates from four unnumbered fields in Yadkın County 
July can be accounted for onl by high levels of initial inoculum Fvidently, $B$ zeicola is better adapted than either $B$ mavdis or $E$ iurcicum for survival during its saprophytic phase in corn crop debris under the environmental conditions in North Carolina As the growing season progresses $B$ maidis and $E$ turcuum populations overtake those of $B$ zelcola because of their greater capacity for reproduction on living corn leaves The lesions induced by $B$ zeicola are small and sporulation generally does not occur in them until the leaves senesce (19) Conidia of $B$ zeicola however are capable of infecting corn ledves in all stages of the plant's development Thus $B$ zeic ola is effective in establishing itself in living corn leaves before they can be invaded by saprophytes but it causes little damage to the plant In this way $B$ zt cola occupies an ecological niche between that of an aggressive parasite and that of an opportunistic saprophite

Io be successful in the niche to which it has adapted $B$ zelcola must sporulate profusely after the infected ledves senesce and must compete strongly with other microorganisms to maintain itsell in the dead host tissue until the next growing season the success of $B$ zicola is enhanced by its ability to invade and survive in stalks as well as ledves of corn (1) In the comparison of $B$ zeic ola with $B$ maldis it appears that by ddapting to increasingly aggressive parasitism the pathogen sacrifices part of its ability to survive saprophytically and vice versa

Wheat and corn often are grown in ddjacent small fields in North C a rolına or in the same fields in successive seasons in a corn winter wheat, soybean rotation so it is not so surprising that conidia of $B$ sorokıniana can be found in cornfields Kline and Nelson $(6,21)$ showed that $B$ sorokiniana has a broad host range, but their isolates were avirulent to corn seedlings inoculated in the greenhouse Our results show that $B$ sorokiniana can infect adult corn plants in the field In field 6 in Yadkin County, the incidence of $B$ sorokiniana in corn leaves was $37 \%$ This indicates that most of the corn plants must have carried $B$ sorokiniane infections in at least one leaf Such an abundance of the pathogen in corn leaves would provide significant initial inoculum for infection of a wheat crop in the field in a corn, winter wheat, soybean rotation

Northern leaf blight, as its name suggests is not a common problem of corn in the Southeast The disedse occurs sporadically in North Carolind, with epidemics at inf requent intervals of up to $10 \mathrm{yr}$ Because temperatures are cooler in the mountains and western Pledmont than in eastern North Carolina, $E$ turcicum is found more frequently in corn in the western counties, as it was in the 1985 survey In contrast, southern leaf blight caused by $B$ maydis is common in North Carolina and tends to be more severe in eastern than in western North Carolina (11) In 1985 B maıds incidence appeared to be slightly greater in the two extensively sampled fields in eastern North Carolina than in the western fields, but the differences were not significant

$E$ rostratum has a ver brodd host range and has often been reported in leaves of corn and othes gramineous species (12 29) Its pathogenicity to corn resembles that of $B$ zelcola but the incidence of $I$ rostratum in corn leaves in North Carolina in 1989 was much lower than that of $B$ zeccola It seems likely that $E$ rostratum is less efficient than $B$ zelc ola in infecting green leaves of adult corn plants Like $B$ zewola $F$ rostratum can invade the stalkı of mature corn plants (7) This undoubtedls enhances its ability to survive saprophitically and produce abundant inoculum for the following growing sedson

The presence of $F$ holmu in ledves of corn plants in field 9 in McDowell County suggests that Dastiloctenum the known host of $F$ holmn must have been abundant around the edges of that cornfield We suspect that the unidentified Bipolars species tound in field 9 is probably also a pathogen of a grass that was common at the edges of the field

The presence of $A$ holmu $B$ sorokiniani and the unidentitied Bipolaris species in leaves of adult corn plants at incidences ds high as $37 \%$ raises the possibility that the coin pathogens $B$ maidis and $E$ turcicum may also invade leaves of grasses and small grains in the vicinity of curnfields Dead ledves of these plants might $x$-ve as sources of inoculum for corn during the following growing season

In virulence tests, we found no evidence of $\mathrm{a}$ race virulent on corn with cms-C as reported in China (28) Whereas this information is welcome in terms of the prospects for hybrids with $\mathrm{cms}-\mathrm{C}$ in the immediate future, it does not ensure contınued safe use of cms-C in the production of future hybrids in the United States Evidence from the epidemic caused by race $T$ of $B$ maydis in 1970 shows that such a race of $B$ maydss

Table 3 Mating type" frequencies among solates of Bipolaris zetcola and $B$ maydis isolates collected from leaves of Zea mavs in five cornfields ${ }^{b}$ in North Carolina in 1985

\begin{tabular}{lcccccc}
\hline & & & \multicolumn{3}{c}{ Frequency of MAT1-1 (\%) } \\
\cline { 5 - 6 } & Field & & \multicolumn{3}{c}{ B zeicola } \\
\cline { 5 - 6 } County & no & Date & Race 2 & Race 3 & Total & B maydas \\
\hline Wilkes & 1 & $7 / 16$ & 24 & 38 & 28 & 23 \\
Wilkes & 2 & 716 & 76 & 67 & 71 & 29 \\
Edgecombe & 7 & $7 / 24$ & 22 & 46 & 31 & 62 \\
McDowell & 9 & $7 / 25$ & & & 83 & 43 \\
Wake & 8 & $7 / 28$ & & & 59 & 28 \\
Mean & & & 407 & 503 & 494 & 348 \\
\hline
\end{tabular}

"MAT1-1 and MA71-2 were formerly designated as $A$ and a respectively

"Only fields with greater than $10 \%$ incidence of $B$ zeicola and $B$ maydis in the leaves are included, fields 8 and 9 had less than $5 \%$ incidence of race 3 of $B$ zeicola could arise and spread throughout the corn-growing areas of North America within a tew vear if susceptible hybrid were to be extensiveli grown (15) On the ther hand the evidence of race $T$ also indicates that such a race will probably not arise if susceptible hrbrids are not Inted States We found no maids that we collected in 1985 This is quichly disappeared from the $B$ maid population of the Southeast after the use of $\mathrm{cms}-\mathrm{I}$ in the production of hybrid corn seed was abandoned (13 15)

As we reported earlier (16) our evidence indicates that the 1985 epide mic of northein corn leaf blight in western North Carolina was caused by race I of $F$ iurcicum Although race 2 did eventually increase on corn hybrids with e gene $H I l$ for resistance to race 1 there race 2 was extremely low edily in 1985 or the genotspes of race 2 present are les ggressive than those of race 1

Pedersen and Brandenburg (23) Ported that 27 of 65 ssolates of race 20 E lurckum collected over a wide geographical arca from Delaware to lowa were mating type a and that the other 38 isolates falled to form pseudothecla in any mating tests We also had difficulty inducing pseudothecial proour three race 2 isolates were sufficiently fertile to identify mating types, both were mating type a Although the evidence is the situation seems imilar to that in race $T$ of $B$ mavdis in which a single matıng type predominated new race of the pathogen, particularly in the Corn Belt and United States (10) More fertile testers of $E$ turcicum must be fentified so that the mating types of a determined if, indeed, all isolates of race 2 of $E$ turcicum are matıng type a, that would indicate that hybridization between race 1 and race 2 has rarely, if ever, occurred in the field. On the basis of that possibility and the possibility that race Tisolates among the 75 isolates of $B$ Ether the amount of initial inoculum of 
race 2 is less aggressive than race 1 , it is important that every precaution should be taken to prevent laboratory recombinants between the two races from escaping to the field.

Frequencies of the two mating types of $B$. zetcola and $B$. maydis fluctuate from year to year and from field to field, but with the exception of the first years of occurrence of race $\mathrm{T}$ of $B$. mavdis in the United States, both mating types can be found at reasonably high frequencies in any population of either species. The persistence of the mating type polymorphism is typical of systems of frequency-dependent selection. In stable polymorphisms protected by frequencydependent selection, whichever allele is less frequent in the population tends to have a selective advantage. Frequencydependent selection would occur if the sexual stage was essential to survival of these fungi, but there is no evidence that pseudothecia and ascospores are even common in nature, much less essential.

Thus, it appears that some other type of frequency-dependent or balancing selection must account for the persistence of the mating type polymorphism in $B$. zeicola and $B$. maydis Although the evidence from just three fields is 100 limited to be convincing, there is some indication that within fields, selection may affect mating types in races 2 and 3 of $B$. zeicola similarly. At least, the frequencies of mating types of races 2 and 3 appeared to be correlated, whereas the frequencies of mating types over both races of $B$. zeicola were not correlated with mating type frequencies in $B$. mal'dis in the same fields. This suggests that putative factors responsible for frequency-dependent selection of mating types differ for different species of Bipolaris. Lodge and Leonard (19) found a general similarity of matıng type frequencies in races 2 and 3 of B. zeicola over rather broad geographical regions of North Carolina. Further comparisons of matıng type frequencies of races 2 and 3 of $B$. zeicola in samples from other fields sampled in 1985 will be reported in a separate paper.

\section{LITERATURE CITED}

I Anderson. B. and White. D G 1987 Fung associated with cornstalks in Illinoss in 1982 and 1983 Plant Dis 71135.137

2 Berquist, $R$ R, and Masias, $O$ R 1974 Physiologic specialization in Trichometasphaerio turcica t in zeae and $T$ turcica of sp sorght in Hawan Phytopatholngy 64 645-649

3 Fisher, D E. Hooker, A I . Lim, S M and Smith. D R 1976 leaf infection and yield loss caused by four Helminthosporium leal discases of corn Phytopathology 66 942-944

4 Hebert. T I 1971 The periect stage of Pyricularia grisea Phytopathology 61 B3-87

5 Jordan, E G, Perkıns, J M , Schall, R A and Pedersen, $W$ L 1983 Occurrence of race 2 of Exserohilum lurc ic um on corn in the central and castern United States Plant [1/s 67 I16.3-1165

6 Kline, D $M$ and Nelson, $R$ R 1963 Pathogenicity of solates of Cochloholus sativus from cultivated and wild gramineous hosts from the Western Hemisphere to species of the Gramineac Plant Dis Rep $47890-894$

7 Kucharek. T A 1973 Stalk rot of corn caused by Helminhosporium rostratum Phvtopathology $63 \quad 1336-1338$

8 I cath. S and Leonard, K J 1986 Distribution of race 3 of Corhliobolus carbonus on corn in North Carolina Plant Dis 70800

9 Leonard, K J 1972 Helminthosporium upn as laboratory contaminants on incubated lea specimens Plant Dis Rep 56 8.34-8.36

10 leonard, K J 1973 Assoclation of mating type and virulence in Heiminthosporium masdis, and observations on the origin of the race I population in the United States Phytopatholog) 6.3112 .115

11 Leonard, K I 1974 Foliar pathogens of corn in North Carolina Plant Dis Rep 58532.534

12 Leonard, K I 1976 Synonomv of Exserohilum halodes with $t$ rosiratum, and induction of the ascigcrous state. Setosphaeria rostrata Mycologia 68402.411

13 I eonard. K J 1977 Races of Bipolars maids in the southeastern US from 19741976 Plant Dis Rep 61914.915

14 Leonard. K J 1978 Polymorphisms for lesion type, fungicide tolerance. and matıng capacit) in
Cochliobolus carbonum isolates pathogenic to corn Can J Bot 56 1809-1815

15 Leonard, K J 1987 The host population as a selective factor Pages 161-179 in. Populations of Plant Pathogens Thejr Dynamics and Genetics M S Wolfe and C E Caten. eds Blackwell Scientific Publications. Oxford, England

16 Leonard, K J, and Leath. S 1986 Evidence that race I of Setosphoena turcua caused the 1985 northern corn leaf blight epidemic in North Carolina Plant Dis 70981

17 Leonard, K J., and Suggs, E G 1974 Setosphaeria prolata, the ascigerous state of Exseruhilum prolatum Mycologia 66.281-297

18 Lipps. P F 1982 Exserohilum iurcicum virulent on corn with the $H i$ resistance gene in Ohio Plane Dis 66 397.398

19 I odge. D J, and Leonard, K J 1984 A cline and other patterns of genetic variation in Cochliobolus carbonum isolates pathogenic to corn in North Carolina. Can J Bot 62 995-1005

20 Luttrell, F S 1963 A Trichometasphaeria perfect stage for a Helminthosporium causing a leaf blight of Dactvloctenium Phytopathologi $53.281-285$

21 Nelson, $R$ R, and Kline, D $M|96|$ Ihe pathogenicity of certuin species of Heiminthosporium to species of the Gramineae Plant Dis Rep 45.644-648

22 Nelson, $R$ R, and Kline, D $M$ 1966 The pathogenicity of 91 morphologically similar solates of Helminthosporium to 30 gramineous specier Plant Dis Rep 50 382-384

23 Pedersen. W I , and Brandenburg. I J 1986 Matung types, virulence, and cultural characteristics of Ex serohilum iurcicum race 2 Plant Dis $70290-292$

24 Subramanian. C V 1956 Hyphomycetes II J Indian Bot Soc 35 446-449

25 Tuite, J 1969 Plant Pathological Methods Burgess Publishing Co. Minneapolis, MN $239 \mathrm{pp}$

26 I urner, M I and Johnson, F R 1980 Race of Helminthosporium turs u um not controlled by $H t$ genetle resistance in corn in the American corn belt Plant Dis 64 216-217

27 Ullstrup. A J 1944 Further studies on a species of Helminthosporium parasitizing corn Phvtopathology $\$ 4$ 214-222

28 Wel. J-K . Liu, K-M . Chen, I-P and leeStadelmann, O Y 1988 Pathological and physiological identification of race $C$ of Bipolaris mavdis in China Phytopathology $78550-554$

29 Whitehead, M D, and Calvert, O H 1959 Helmunthosporium rostralum inciting ear rot of corn and leal-spot of thirteen grass hosts Phytopathology $49817-820$ 